\title{
Konsep dan Strategi Upaya Pelestarian Kerajinan Laker Palembang Melalui Pelatihan dan Workshop
}

\author{
Husni Mubarat ${ }^{1)}$, Safar Junoko ${ }^{2)}$ \\ ${ }^{12)}$ Program Studi Desain Komunikasi Visual, Universitas Indo Global Mandiri \\ Jl Jend. Sudirman No. 629 KM. 4 Palembang Kode Pos 30129 \\ Email: husni_dkv@uigm.ac.id ${ }^{1)}$, safarjunoko@gmail.com ${ }^{2)}$
}

\begin{abstract}
This research is focused on aspects of the Process and Identification of Lkauer Crafts in Palembang, with the objectives being, 1) to support efforts to preserve the art of laker crafts in Palembang, 2) to find out the development of the design of the laker craft, 3) to find out the local cultural values contained in Palembang laker crafts, 4) to add insight and teaching materials to art and design lectures, especially DKV. The method used is descriptive qualitative method, with the method of collecting field observation data, which is to see firsthand the laker handicraft products in the craft center, and at the Bala Putra Dewa Museum in Palembang, the data collection method is also carried out by interviewing techniques and documenting the object research. The results of the data processing are the authors' analysis through the identification of problems encountered in the field. From these results the conclusions drawn by the author are summarized in the form of a draft strategy for the preservation of the laker craft. In addition to preservation efforts, the laker craft can also provide business opportunities and employment opportunities for the people of Palembang city, of course it cannot be separated from the assistance of the Regional Government in the form of training, workshops, capital assistance as well as providing a place for marketing.
\end{abstract}

Keywords : Laker Crafts, Development, Preservation, Palembang

\begin{abstract}
Abstrak
Penelitian ini difokuskan pada aspek Proses dan Identifikasi Kerajinan lakaer di Palembang, dengan tujuan, 1) untuk mendukung upaya pelestarian seni kerajinan laker di Palembang, 2) untuk mengetahui perkembangan desain laker. kerajinan, 3) untuk mengetahui nilai-nilai budaya lokal yang terkandung dalam kerajinan laker Palembang, 4) untuk menambah wawasan dan bahan ajar untuk kuliah seni dan desain, khususnya DKV. Metode yang digunakan adalah metode deskriptif kualitatif, dengan metode pengumpulan data observasi lapangan, yaitu untuk melihat langsung produk kerajinan tangan di pusat kerajinan, dan di Museum Bala Putra Dewa di Palembang, metode pengumpulan data juga dilakukan oleh teknik wawancara dan mendokumentasikan objek penelitian. Hasil pengolahan data adalah analisis penulis melalui identifikasi masalah yang dihadapi di lapangan. Dari hasil ini, kesimpulan yang ditarik oleh penulis dirangkum dalam bentuk konsep strategi untuk pelestarian kerajinan laker. Selain upaya pelestarian, kerajinan laker juga dapat memberikan peluang bisnis dan peluang kerja bagi masyarakat kota Palembang, tentu saja tidak terlepas dari bantuan Pemerintah Daerah dalam bentuk pelatihan, workshop, bantuan modal serta menyediakan tempat untuk pemasaran.
\end{abstract}

Kata kunci: Kerajinan Laker, Pengembangan, Pelestarian, Palembang 


\section{Pendahuluan}

Di tengah derasnya gelombang modernisasi budaya lokal mulai terpinggirkan dari kehidupan masyarakat Indonesia sendiri, terutama bagi generasi muda. Ancaman globalisasi terhadap eksisitensi jati diri bangsa di bidang budaya tersebut tercermin dari semakin terkikisnya budaya lokal. Mempelajari dan menggali potensi budaya lokal seakan dianggap sebagai generasi yang ketinggalan zaman alias kuno.

Fenomena tersebut pada dasarnya cukup mengkhawatirkan bagi bangsa Indonesia, karena budaya lokallah yang membentuk karakter dan jati diri bangsa. Oleh karena itu mencermati fenomena perkembangan zaman, perlu adanya upaya untuk melestarikan dan mengembangkan budaya lokal, agar keberadaan selalu terjaga dari generasi ke generasi.

Kota Palembang merupakan Wilayah Tingkat II sebagai Ibu Kota Provinsi Sumatera Selatan, memiliki kekayaan dan budaya lokal yang beragam dengan potensinya masing-masing, salah satunya adalah seni kerajinan. Kota Palembang memiliki seni krajinan yang beragam, di antaranya adalah Seni Kerajinan Tenun Songket, Seni Kerajinan ukir Kayu, dan seni kerajinan laker.

Masing-masing seni kerajinan tersebut memiliki potensi untuk dapat dikembangkan dalam industri kreatif, tentunya perlu usaha yang serius baik dari pemerintah maupun dari akademisi. Di samping sebagai sarana ekonomi kerakyatan, potensi masing-masing kerajinan tersebut juga dapat menjadi sarana untuk pelestarian kearifan lokal dalam era globalisasi. Agar tulisan ini tidak menjadi luas, penulis memilih seni kerajinan laker sebagai titik fokus masalah yaitu "Pelatihan Kerajinan Laker; Pelestarian dan Pengembangan Desain".

Menurut Bambang Budi Utomo dalam Sargih (1993: 2): Kerajinan lakuer Palembang dapat dikatakan peninggalan masa Sriwijaya, dimana Palembang masih berkembang dengan baik. Tidak seperti kerajinan songket, dan batik dimana produk ini berkembang di wilayah melayu lainnya sampai saat ini. Sedangkan lakuer hanya Palembang yang memproduknya.

Seni kerajinan laker sebagai warisan budaya masyarakat masa lampau yang diwariskan dari generasi ke generasi yang telah berumur ratusan tahun, di mana keberadaanya masih lestari dalam kehidupan global saat ini. Kerajinan laker merupakan sesuatu yang sangat berharga, bernilai sejarah, bernilai estetik dan bernilai tradisi serta bersifat local genius, sehingga dapat dikatakan sebagai salah satu produk kerajinan unggulan Kota Palembang.

Kata Lak atau Laker berasal dari bahasa Inggris yaitu Lacquer berasal dari kata Lac, yaitu nama bahan damar yang dihasilkan oleh sejenis serangga yang bernama Lacifier Lacca. Tumbuhan tempat bertenggernya serangga ini banyak ditemukan di Jepang, Tiongkok, dan di daerah Pegunungan Himalaya. Di Sumatera Selatan pohon tersebut dikenal dengan pohon kemalo (Utomo dalam Saragih dan Ernawati, 1996:1).
Potensi seni kerajinan laker Palembang tidak hanya memiliki nilai budaya dan sejarah sebagai identitas budaya lokal Palembang, namun juga bernilai seni kriya yang unik dan indah serta jenis produk yang beragam dengan nilai fungsinya masing-masing. Nilai-nilai tersebut, tentunya dapat diperhitungkan sebagai sarana industri kreatif bagi masyarakat lokal Palembang (khususnya bagi pengarajin Laker) dalam menghadapi tantangan globalisasi.

Poerwanto, (2010: 13), mengungkapkan bahwa Agar suatu kebudayaan (kesenian) dapat merespon berbagai masalah kelangsungan hidup manusia dan tetap dipelajari oleh generasi berikutnya, sehingga tetap lestari, maka suatu kebudayaan harus mampu mengembangkan berbagai sarana yang dapat diandalkan untuk memenuhi kebutuhan pokok para individu.

Berdasarkan ungkapan tersebut, dapat dipahami bahwa kerajinan laker sebagai budaya lokal Palembang, tentunya tidak dapat dipertahankan sebagai warisan budaya masa lampau tanpa adanya dukungan pemerintah, baik dinas pariwisita, koperindag maupun instansi lainnya sebagai pemegang peranan dalam mendukung pengrajin laker di kota palembang.

Sebagai salah satu upaya pengembangan seni kerajinan laker di Palembang adalah melalui pelatihan dan workshop di taman Budaya Provinsi Sumatera Selatan. Pelatihan ini merupakan suatu usaha bagi taman budaya dan seniman lokal Palembang dalam mempertahankan eksistensi kerajian laker di tengah perkembangan zaman dan kemajuan teknologi dan informasi.

Pelatihan kerajinan laker dilakukan selama lebih kurang tiga bulan, yang mana terdiri dari tiga kategori peserta yaitu tingkat ibu rumah tangga, tingkat pelajar dan pengrajin laker itu sendiri. Program pelatihan kerajinan laker Palembang merupakan langkah awal yang dilakukan oleh Dinas Pariwisata, Taman Budaya yang bekerjasama dengan beberapa seniman laker dari Sanggar Seni Ganesha dalam upaya mengangkat kerajinan laker sebagai salah satu produk unggulan Kota Palembang, yang beberapa tahun ke belakang ini mengalami kemunduran.

Adapun rumusan masalah dalam penelitian ini adalah: 1) Bagaimana usaha pelestarian kerajinan laker melalui pelatihan di Taman Budaya sriwijaya Palembang, 2) Bagaimana merancang strategi pengembangan kerajinan laker Palembang agar tetap lestari, 3) Bagaimana keberadaan kerajinan laker di tengah perkembangan zaman.

Penelitian ini bertujuan untuk: 1) mendukung upaya pelestarian kerajinan laker Palembang, 2) Untuk mengetahui perkembangan desain kerajinan laker Palembang, 3) Untuk mengetahui nilai-nilai budaya lokal yang terdapat pada kerajinan laker Palembang.

Pada penelitian ini penulis menggunakan metode penelitian kualitatif dengan merumuskan rancangan penelitian. Rancangan penelitian merupakan perencanaan, pola atau model penelitian. Menurut Guba dalam Subana (2009: 20), desain penelitian kualitatif 
sangat terkait erat dengan pandangan dasar yang melatar belakanginya, di mana penelitian kualitatif melihat bahwa realitas yang ada itu majemuk secara simultan, serta sangat terkait pada nilai. Berdasarkan ungkapan tersebut, adapun rancangan penelitian yang penulis rancang adalah sebagai berikut:

Bagan 1. Rancangan Penelitian

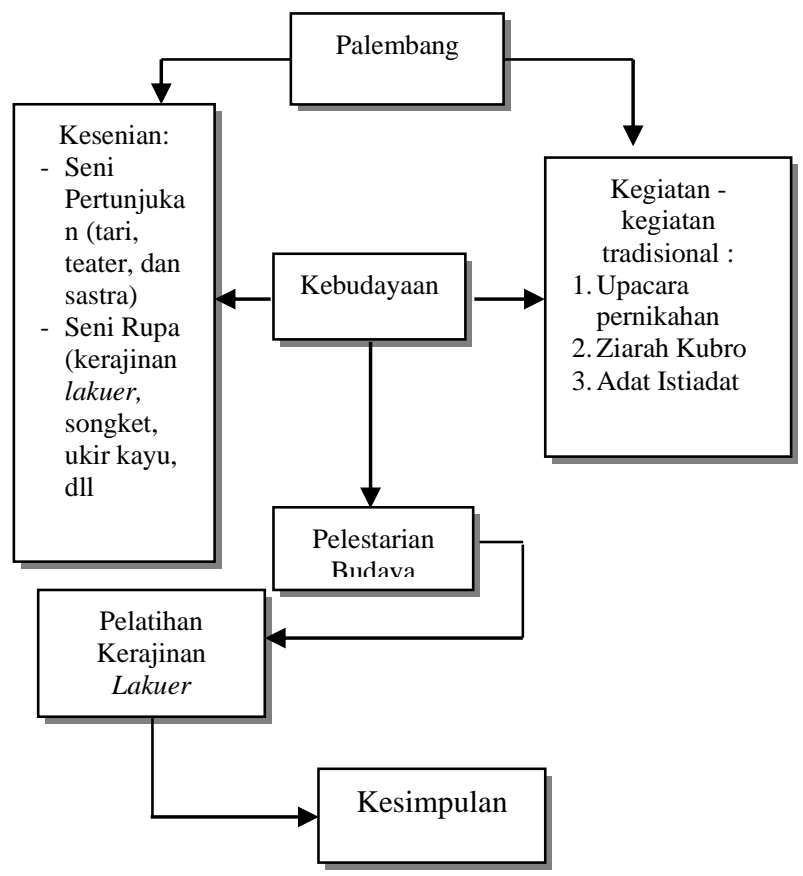

Adapun metode pengumpulan data yang diguanakan adalah: 1) Obesrvasi, dilakukan ke Taman Budaya Sriwijaya Sumatera Selatan Observasi juga dilakukan di museum Bala Putra Dewa SUMSEL sebagai salah satu tempat pelestarian kerajinan laker Palembang. Observasi juga dilakukan dalam bentuk studi pustaka yang bertujuan untuk mecari data-data yang berkaitan dengan objek penelitian, 2) wawancara, dalam penelitian ini wawancara dilakukan dengan beberapa narasumber yang penulis anggap berkompeten di bidang ini, yaitu pihak Taman Budaya Sriwijaya SUMSEL, Muhammad Idris sebagai seniman lukis laker, dan pihak-pihak yang berkaitan dengan penelitian, 3) Dalam penelitian ini dilakukan dengan mencatat data secara sistimatis, baik yang diperoleh melalui buku-buku maupun media massa dan internet. Data-data dokumen ini digunakan sebagai sumber data yang dapat dipergunakan untuk menguji, mendekripsikan dan menapsirkan permasalahan dalam penelitian. Di samping itu, teknik dokumentasi juga dilakukan dengan memotret langsung objek penelitian yaitu Kerajinan Laker Palembang, selanjutnya pemotretan juga dilakukan bagian perbagain motif ragam hias kerajinan laker.

\section{Pembahasan}

\section{A. Upaya Pelestarian Kerajinan Laker Palembang melalui Pelatihan}

Kemampuan teknis para perajin yang terampil bukan saja tampak dari segi ekonomi sosial, tetapi sampai pada sosial masyarakatnya juga meningkat semangat dan keuletan para perajin. Kondisi tersebut terwujud, karena perajin memiliki motivasi yang kuat untuk mempertahankan kesenian ini agar tidak tergeruk oleh modernisasi. Kerajinan laker sudah menjadi ciri masyarakat Palembang karena kerajinan ini diciptakan langsung masyarakat Palembang.

Mengacu pada data wawancara yang penulis lakukan terhadap beberapa nara sumber yang berkompeten di bidang tersebut, secara garis besar mengungkapkan bahwa keberadaan kerajinan lakuer perlu dikembangkan, baik desain, fungsi maupun material yang digunakan. Oleh karenanya untuk melakukan pengembangan harus ada kerjasam antar unit-unit yang berkompeten, sehingga kerajinan tersebut terlestarikan seiring dengan zaman. Di samping terjaga nilai sejarah dan budaya keberadaan kerajinan lakuer juga dapat membawa dampak ekonomi bagi masyarakat, seperti pengembangan dalam bentuk souvenit dan cendera mata.

Di sisi lain peluang yang dapat dimanfaatkan adalah ivent-ivent yang berskala nasional dan internasional yang sering kali diadakan di Kota Palembang. dengan demikian peluang untuk mengembangkan produk kerajinan laluer semakin terbuka.

Pelatihan kerajinan laker yang dilakukan di Taman Budaya Sriwijaya merupakan suatu upaya untuk mempertahankan dan melestarikan kerajinan laker dalam menghadapi perkembangan globalisasi. Pelatihan dilakukan lebih kurang selama tiga bulan dengan berbagai tingkatan peserta di antaranya adalah ibu rumah tangga, pelajar, dan pengrajin laker itu sendiri.

Dalam kegiatan tidak hanya difokuskan terhadap proses dan tahapan pengerjaan kerajinan laker, namun juga dilakukan kegiatan diskusi dan seminar, hal ini bertujuan agar nilai-nilai budaya, sejarah, dan nilai seni yang ada pada kerajinan laker dapat dipahami oleh peserta. Dengan demikian kerajinan laker yang sempat mengalami kemunduran dapat angkat kembali sebagai produk budaya lokal Palembang.

Menurut Muhammad Idris (wawancara, 2019), pelatihan kerajinan laker ini tentunya tidak sebatas memberi pengetahuan terhadap peserta pelatihan dan tidak pula sebatas pelestariannya saja, akan tetapi pelatihan ini diharapkan kerajinan laker ini dapat menjadi produk industri kreatif, sehingga dapat membuka peluang usaha dan peluang kerja bagi peserta pelatihan kerajinan laker.

Selanjutnya Muhammad Idris menyampaikan juga bahwa upaya pelestarian kerajinan laker tentu tidak terlepas dari kondisi perkembangan zaman, yang mana kemajuan teknologi dan informasi tidak hanya berdampak negatif terhadap budaya lokal, namun dapat dimanfaatkan sebagai peluang bagi pelaku usaha dalam mengembangkan pasar dan media promosi suatu produk termasuk produk kerajinan laker. 


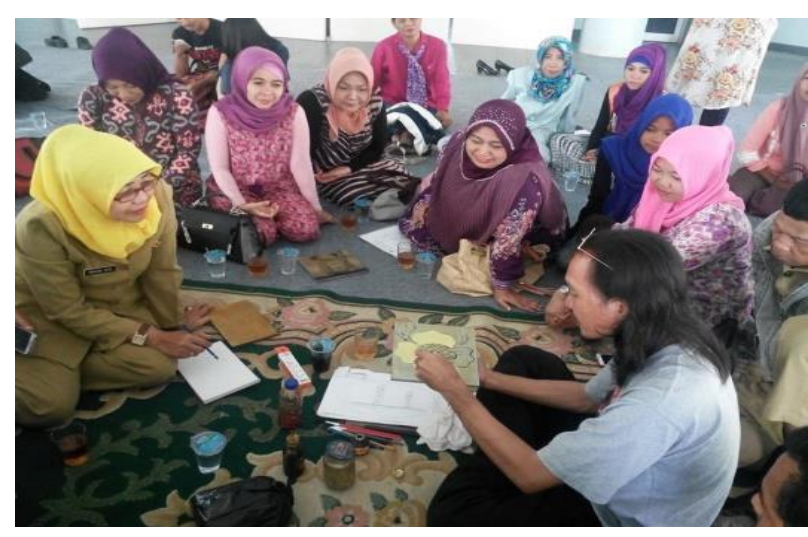

Gambar 1. Pelatihan kerajinan laker bersama ibu rumah tangga di Taman Budaya Sriwijaya. Dokumentasi: Husni Mubarat, 2018.

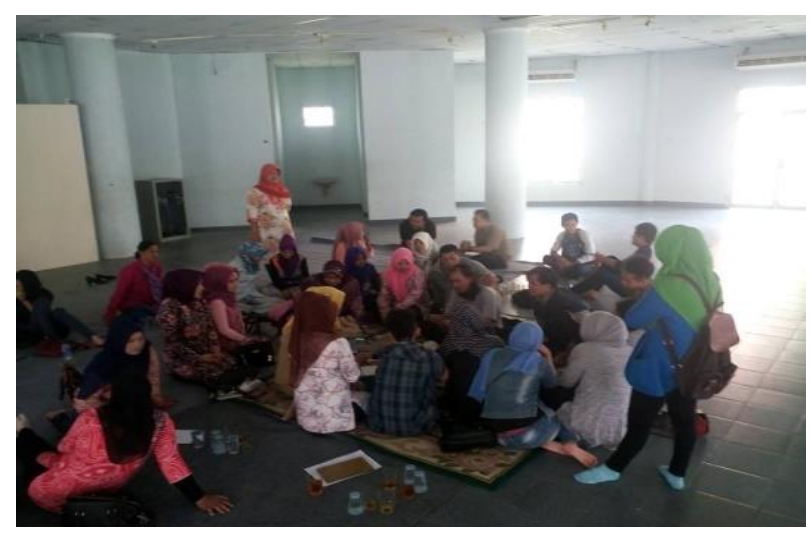

Gambar 2. Pelatihan kerajinan laker bersama ibu rumah tangga di Taman Budaya Sriwijaya. Dokumentasi: Husni Mubarat, 2018.

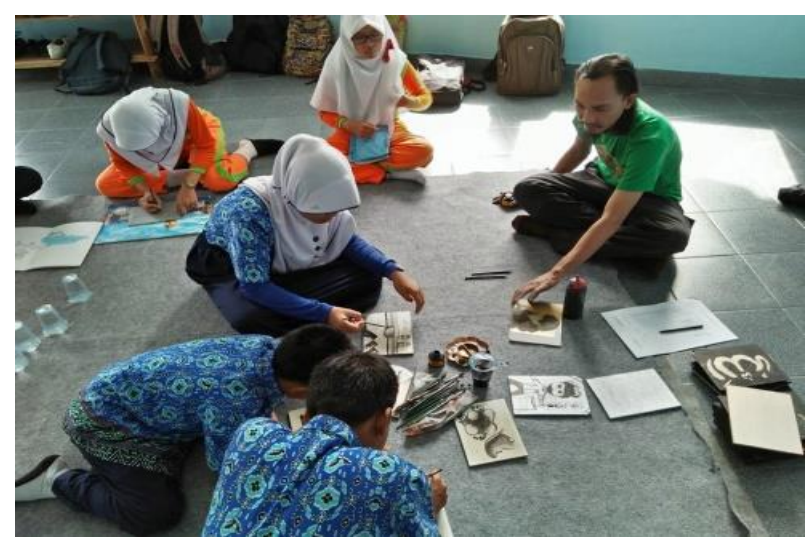

Gambar 3. Pelatihan kerajinan laker bersama Siswal Siswi SMP dan SMA di Taman Budaya Sriwijaya.

Dokumentasi: Husni Mubarat, 2019

\section{B. Upaya Pengembangan Desain Produk}

Keunikan dan kekhasan seni kerajinan tradisi tidak terlepas dari desain produknya. Desain produk kerajinan merupakan desain yang berbasis kriya, merupakan terjemahan dari istilah 'craft design' dan dapat didefinisikan sebagai suatu karya desain yang dilandasi (berbasis) prinsip-prinsip kriya (craft) dalam proses realisasinya. Benda/produk hasil desain produk kerajinan umumnya lebih menitikberatkan pada nilai-nilai keunikan (uniqueness), estetika (keindahan), seni (art), adiluhung, berharkat tinggi, khusus, khas, dan kehalusan rasa sebagai unsur dasar. Sementara dalam pemenuhan fungsinya lebih menekankan pada pemenuhan fungsi pakai yang lebih bersifat fisik (fisiologis), misalnya: benda-benda pakai, perhiasan, furnitur, sandang, dan sebagainya. Pemenuhan atas fungsi yang bersifat nonfisik bisa dikatakan relatif kecil.

Desain menurut Agus Sachari dan Yan Yan Sunarya (1999 : 4), sebagai inti karya budaya fisik yang lahir dari berbagai pertimbangan pikir, gagas, rasa, dan jiwa perancangnya (desainer fashion, pen.), yang didukung oleh faktor luar menyangkut penemuan-penemuan di bidang ilmu dan teknologi, lingkungan sosial, tatanilai, dan budaya, kaidah estetika, kondisi ekonomi dan politik, hingga proyeksi terhadap perkembangan yang mungkin terjadi di masa depan.

Jika diamati secara keseluruhan, ada banyak jenis produk dan fungsi kerajinan lakuer Palembang, dari benda-benda yang bersifat cenderamata sampai pada benda-benda kerajinan yang bersifat furnitur. Dapat dikatakan hampir semua kerajinan perabotan di sentrasentra kerajinan Palembang yang menggunakan material kayu memiliki sentuhan kerajinan lakuer.

Mengacu pada ciri-ciri produk kerajinan lakuer yang ada di Museum Bala Putra Dewa dan produk-produk kerajinan lakuer yang terdapat di industri kerajinan serta yang ada di Sanggar Ganesha, dapat ditarik kesimpulan bahwa perkembangan desain kerajinan lakuer terdiri dari tiga tahap, yaitu dari desain produk yang berkaitan dengan sarana budaya, produk yang berkaitan dengan penunjang sarana keluarga, dan produk yang berkaitan dengan souvenir, cenderamata, dan lukisan lakuer.

\section{Analisis SWOT sebagai upaya mengukur produk Kerajinan Laker}

Berdasarkan riset, survey dan penelitian atas laker Palembang dan produk kerajinan laker khas Palembang, penulis berharap agar penelitian ini dapat menjadi suatu gagasan berkarya dengan metode-metode dan media baru yang alamiah yang mampu membawa kekhasan budaya nusantara yang mampu bersaing dan mampu dilihat oleh mata dunia, terutama laker Palembang yang merupakan warisan nusantara yang khas yang hanya dimiliki oleh Palembang (untuk wiayah Indonesia) dengan segala keunikan dan kelebihan yang tentunya tidak kalah bersaing dengan Chinese Lacquer dan teknik laker alami lainnya yang ada di berbagai penjuru dunia bila lebih dikenal, dihargai, dipromosikan dengan bantuan masyarakat dan seniman di Indonesia.

Berikut merupakan analisis SWOT terhadap laker Palembang sebagai acuan pengetahuan dasar pengaplikasian berkaraya dengan teknik laker khas Palembang :

1. Strenght $(\mathrm{S})$

Kekuatan pada laker khas Palembang adalah : 
a. Memiliki kekhasan warna.

b. Memberikan keawetan terhadap media yang dilapisi.

c. Memberikan kesan mewah dan eksklusif.

d. Memberikan nilai lebih terhadap media dasar yang dipakai.

e. Eksklusif karena bahan baku hanya ditemukan di Sumatra Selatan (untuk Indonesia).

f. Mempunyai nilai jual yang tinggi yang tidak kalah dengan Chinese Lacquer dan laker alami lainnya karena memiliki kualitas dan keindahan yang sama, karena bahan baku laker ini sendiri dari serangga yang sama.

g. Sifatnya yang mengkilap menjadi daya tarik tersendiri dengan efek monokromatis yang membawa warna khas Palembang.

h. Aplikatif, mampu diterapkan pada karya dengan berbagai cabang keilmuan senirupa maupun desain.

i. Merupakan kekhasan budaya daerah sebagai simbol keberagaman suku bangsa di Indonesia

2. Weakness $(W)$

Kelemahan pada laker khas Palembang adalah :

a. Bahan baku tidak selalu ada untuk untuk didapatkan mengingat faktor alam dan cuaca yang mempengaruhi.

b. Proses pengerjaan yang membutuhkan waktu lama mengingat proses pengolahan yang masih tradisional dan manual.

c. Pembuatan penyelesaian karya tergantung dengan kondisi cuaca terutama dalam pengeringan lapisan laker yang dikarenakan proses pengeringan hanya bisa dilakukan oleh sinar matahari dan tidak bisa dilakukan oleh pengering atau pemanas karena akan membuat permukaan laker menjadi retak dan jelek.

d. Kombinasi warna tidak terlalu banyak karena laker yang bersifat monokrom.

3. Opportunities $(\mathrm{O})$

Peluang pada laker khas Palembang adalah :

a. Kerajinan laker Palembang dapat dikembangkan menjadi industri kreatif

b. Laker Palembang mampu mengembangkan kreativitas akan hal dan media baru yang dapatmenyesuaikan dengan berbagai cabang keilmuan senirupa dan desain.

c. Akan mudah dikenali karena memiliki kekhasan dan keunikan yang berbeda dari media-media seni sejenis.

4. Threat $(\mathrm{T})$

Ancaman pada laker khas Palembang adalah :

a. Kurangnya dukungan pemerintah setempat dalam mensupport keberadaan dan potensi laker dan bahan baku laker di Sumatra Selatan.

b. Bahan baku (kemalo) yang mulai langka, karena faktor alam.

c. Kemajuan teknologi yang pesat, sehingga banyaknya produk-produk kerajinan pabrikan yang harganya lebih murah, seperti baki, wadah tissue, wadah permen, dan lain sebagainya.

\section{Rancangan Strategi Pelestarian Kerajinan Lakerer}

Strategi pelestarian kerajinan lakerer merupakan hasil dari pengamatan, wawancara, dan analisis data yang penulis lakukan. Hasil pengolahan data tersebut penulis analisis melalui identifikasi masalah-masalah yang ditemui di lapangan. Dari hasil tersebut dilakukan penarikan kesimpulan yang penulis rangkum dalam bentuk rancangan strategi pelestarian kerajinan lakerer. Adapun rancangan tersebut adalah sebagai berikut:

Bagan 2. Skema/ rancangan pelestarian kerajinan lakerer Palembang
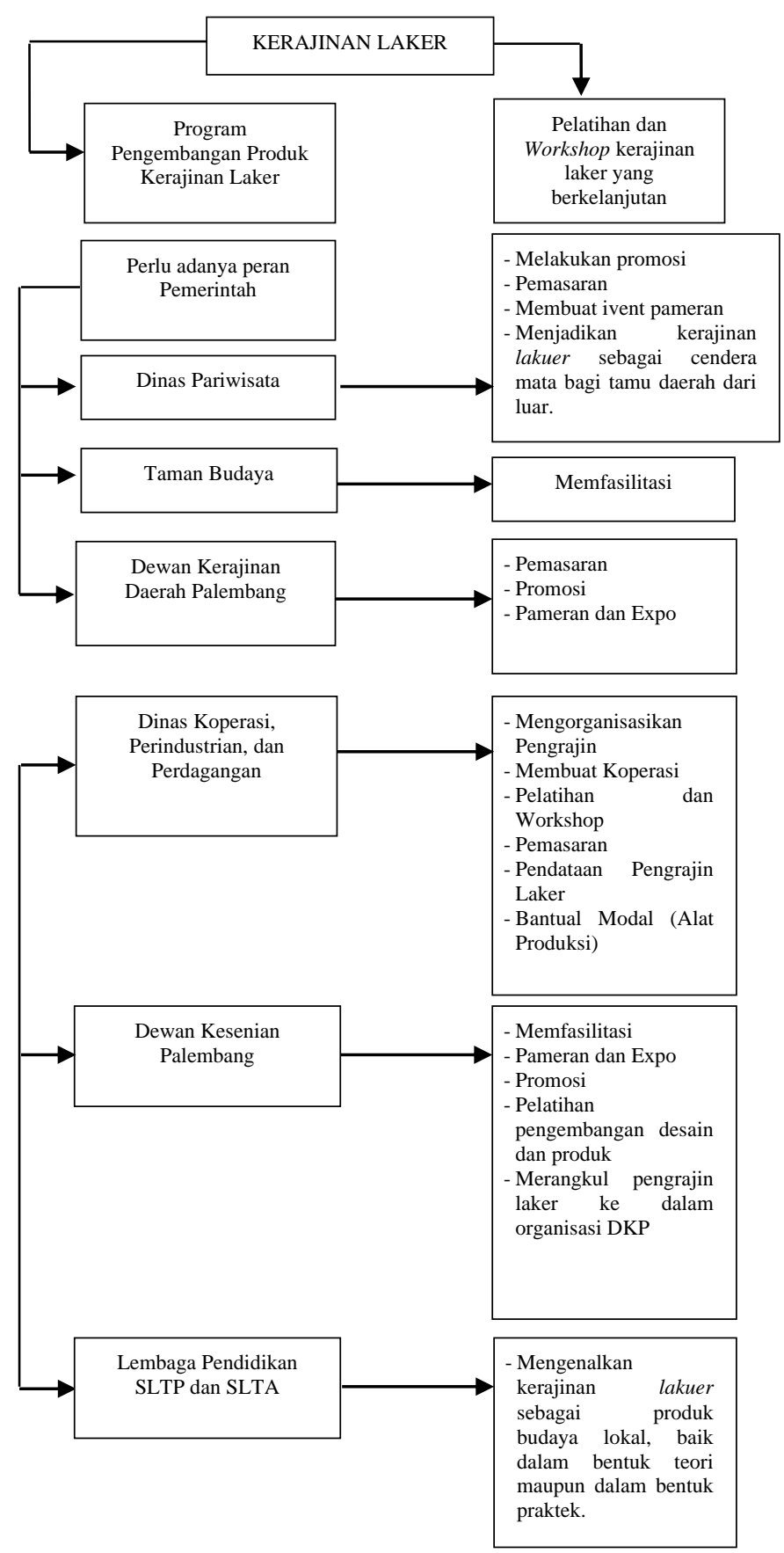


\section{E. Produk Hasil Pelatihan Kerajinan Laker}

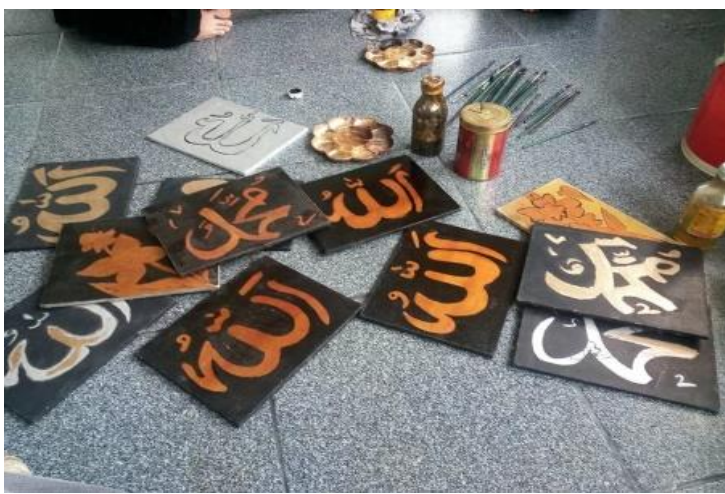

Gambar 4. Hasil Pelatihan kerajinan laker bersama Siswa/ Siswi SMP dan SMA di Taman Budaya Sriwijaya. Dokumentasi: Husni Mubarat, 2019.

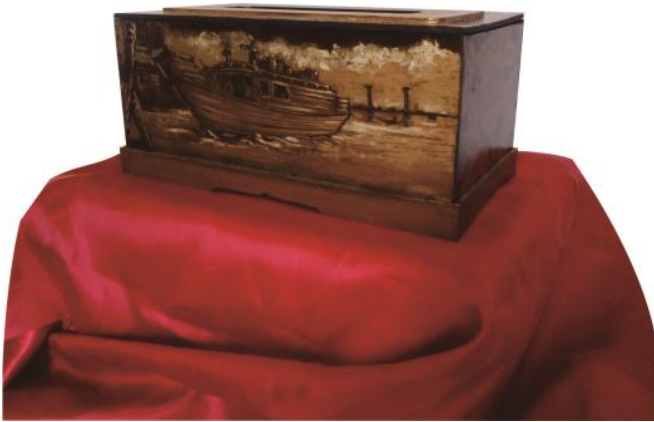

Gambar 5. Wadah tissue lukis laker. Hasil Pengabdian Kemitraan Masyarakat Hibah KemRistekdikti 2019. Dokumentasi: Husni Mubarat, 2019.

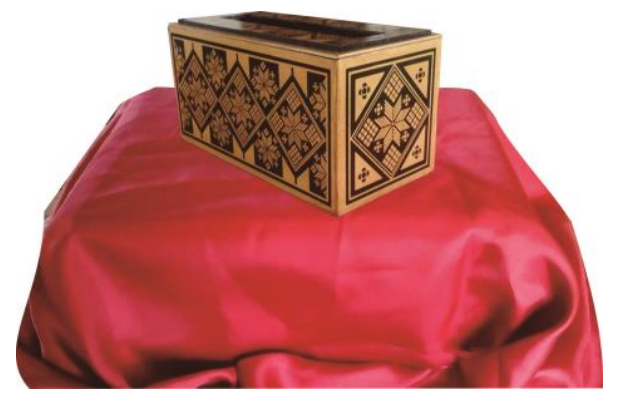

Gambar 6. Wadah tissue lukis laker. Hasil Pengabdian Kemitraan Masyarakat Hibah KemRistekdikti 2019.

Dokumentasi: Husni Mubarat, 2019.

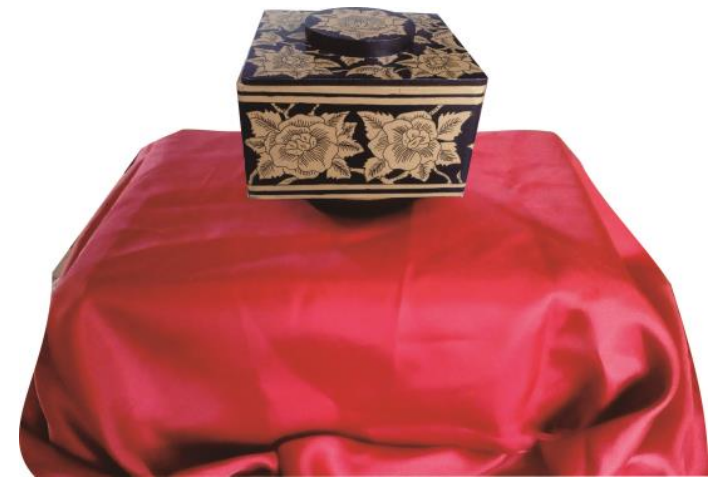

Gambar 7. Wadah tissue lukis laker. Hasil Pengabdian Kemitraan Masyarakat Hibah KemRistekdikti 2019.

Dokumentasi: Husni Mubarat, 2019.

\section{Kesimpulan}

Kerajinan lakerer sebagai warisan budaya lokal Palembang memberi kesempatan bagi generasi muda untuk mempelajari kearifan lokal dalam upaya pelestarian. Indonesia sebagai bangsa yang kaya dengan keanekaragaman budaya lokal seharusnya mati-matian melestarikan warisan budaya agar keberadaannya terjaga. Melestarikan tidak berarti membuat sesuatu menjadi awet dan tidak mungkin punah. Melestarikan berarti memelihara untuk waktu yang sangat lama. Jadi upaya pelestarian kerajinan lakerer sebagai warisan budaya lokal berarti upaya memelihara warisan budaya lokal untuk waktu yang sangat lama maka perlu dikembangkan pelestarian sebagai upaya yang berkelanjutan (sustainable). Jadi bukan pelestarian yang hanya mode sesaat, berbasis proyek, berbasis donor dan elitis (tanpa akar yang kuat di masyarakat). Pelestarian kerajinan lakerer tidak akan dapat bertahan dan berkembang jika tidak didukung oleh masyarakat luas dan instansi ataupun dinas pemerintah yang memiliki peranan dan tanggung jawab.

Pelestarian kerajinan lakerer akan terlakersana jika berbasis pada kekuatan dalam, kekuatan lokal, kekuatan swadaya. Karenanya sangat diperlukan penggerak, pemerhati, pecinta dan pendukung dari berbagai lapisan masyarakat. Untuk itu perlu ditumbuhkembangkan motivasi yang kuat untuk ikut tergerak berpartisipasi melakersanakan pelestarian, antara lain:

1. Motivasi untuk menjaga, mempertahankan dan mewariskan kerajinan lakerer dari generasi sebelumnya ke generasi berikutnya,

2. Motivasi untuk meningkatkan pengetahuan dan kecintaan generasi penerus terhadap nilai-nilai sejarah, nilai budaya, estetika dan nilai ekonomi yang ada pada kerajinan lakerer,

3. Motivasi ekonomi yang percaya bahwa nilai kerajinan lakerer akan meningkat bila terpelihara dengan baik sehingga memiliki nilai komersial untuk meningkatkan kesejahteraan pengampunya.

\section{Daftar Pustaka}

Sachari, Agus. 2002. Estetika, Makna, Simbol dan Daya. Penerbit ITB, Bnadung.

Saragih, Meriati S, dkk. 1997. Kerajinan Laker Palembang. Departemen Pendidikan Dan Kebudayaan Sumatera Selatan, Palembang.

Subana, M. 2009. Dasar-Dasar Penelitian Ilmiah. CV. Pustaka Setia, Bandung.

Suryanegara, Erwan. Syamsul Noor Al Sajidi \& Edy Fahyuni. 2009. Ragam Hias Sumatera Selatan. Dinas Pendidikan Provinsi Sumatera Selatan, Palembang.

Sumber Internet:

- http://nagiyaalya.blogspot.com/2013/03/pentingnyamelestarikan-budaya-indonesia.html). 
Sumber Wawancara :

Nama : Muhammad Idris

Umur : 34 Tahun

Alamat : Jalan KH. Ahmad Dahlan, No. 74 Kota Palembang.

Pekerjaan : Seniman (Pelukis Laker) 